\title{
In vivo hypotensive effect and in vitro inhibitory activity of some Cyperaceae species
}

\author{
Monica Lacerda Lopes Martins' ${ }^{1}$, Henrique Poltronieri Pacheco', Iara Giuberti Perini', Dominik \\ Lenz $^{1}$, Tadeu Uggere de Andrade ${ }^{1, *}$, Denise Coutinho Endringer ${ }^{1,2, *}$
}

\author{
${ }^{1}$ Department of Pharmacy, University of Vila Velha, Vila Velha, ES, Brazil, ${ }^{2}$ Campus Vila Velha, Federal Institute of Espirito
} Santo, Vila Velha, Brazil

\begin{abstract}
In 1820, French naturalist August Saint Hillaire, during a visit in Espírito Santo (ES), a state in southeastern Brazil, reported a popular use of Cyperaceae species as antidote to snake bites. The plant may even have a hypotensive effect, though it was never properly researched. The in vitro inhibitory of the angiotensin converting enzyme (ACE) activity of eigth ethanolic extracts of Cyperaceae was evaluated by colorimetric assay. Total phenolic and flavonoids were determined using colorimetric assay. The hypotensive effect of the active specie (Rhychonospora exaltata, ERE) and the in vivo ACE assay was measured in vivo using male Wistar Kyoto (ERE, $0.01-100 \mathrm{mg} / \mathrm{kg}$ ), with acetylcholine (ACh) as positive control $(5 \mu \mathrm{g} / \mathrm{kg}$, i.v.). The evaluation of ACE in vivo inhibitory effect was performed comparing the mean arterial pressure before and after ERE $(10 \mathrm{mg} / \mathrm{kg}$ ) in animals which received injection of angiotensin I (ANG I; 0,03, 03 and $300 \mu \mathrm{g} / \mathrm{kg}$, i.v.). Captopril (30 mg/kg) was used as positive control. Bulbostylis capillaris $(86.89 \pm 15.20 \%)$ and ERE (74.89 $\pm 11.95 \%$, ERE) were considered active in the in vitro ACE inhibition assay, at $100 \mu \mathrm{g} / \mathrm{mL}$ concentration. ACh lead to a hypotensive effect before and after ERE's curve $(-40 \pm 5 \%$ and $-41 \pm 3 \%$ ). ERE showed a dose-dependent hypotensive effect and a in vivo ACE inhibitory effect. Cyperaceae species showed an inhibitory activity of $\mathrm{ACE}$, in vitro, as well as high content of total phenolic and flavonoids. ERE exhibited an inhibitory effect on both in vitro and in vivo ACE. The selection of species used in popular medicine as antidotes, along with the in vitro assay of ACE inhibition, might be a biomonitoring method for the screening of new medicinal plants with hypotensive properties.
\end{abstract}

Uniterms: Cyperaceae/species/pharmacognosy. Cyperaceae/species/in vitro inhibitory activity. Cyperaceae/species/in vivo hypotensive effect. Angiotensin converting enzyme/in vitro inhibitory. Flavonoids/determination.

Em 1820, o naturalista francês August Saint Hillaire, durante uma visita ao Espírito Santo (ES), Estado do sudeste do Brasil, relatou o uso popular de espécies de Cyperaceae como antídoto para picadas de cobra. As espécies podem possuir efeito hipotensor, embora nunca tenham sido devidamente pesquisadas. A inibição in vitro da atividade da enzima conversora da angiotensina (ECA) de oito extratos etanólicos de Cyperaceae foi avaliada por ensaio colorimétrico. Totais de fenólicos e flavonóides foram determinados utilizando ensaio colorimétrico. O efeito hipotensor da espécie ativa (Rhychonospora exaltata, ERE) no ensaio de ECA in vitro foi avaliada in vivo utilizando-se machos Wistar Kyoto (ERE, 0.01-100 mg/ $/ \mathrm{kg}$ ), com a acetilcolina (ACh), como controle positivo ( $5 \mu \mathrm{g} / \mathrm{kg}$, iv). A avaliação do efeito inibidor da ECA in vivo foi realizado comparando-se a pressão arterial média, antes e após ERE $(10 \mathrm{mg} / \mathrm{kg})$ nos animais que receberam injeção de angiotensina I (Ang I, 0,03, 03 e $300 \mu \mathrm{g} / \mathrm{kg}$, iv). Captopril $(30 \mathrm{mg} / \mathrm{kg}$ ) foi utilizado como controle positivo. Bulbostylis capillaris $(86,89 \pm 15,20 \%)$ e ERE $(74,89 \pm 11,95 \%$, ERE) foram considerados ativas no ensaio de inibição da ECA in vitro, na concentração de $100 \mu \mathrm{g} / \mathrm{mL}$. A ACh gerou um efeito hipotensor, antes e depois da curva de ERE (-40 $\pm 5 \%-41 \pm 3 \%)$. ERE apresentou efeito hipotensivo dependente da dose e um efeito inibidor da ECA in vivo. As espécies de Cyperaceae mostraram uma atividade inibidora de ACE in vitro, bem como elevado conteúdo de substâncias fenólicas

\footnotetext{
*Correspondence: D. C. Endringer. Universidade de Vila Velha. Rua Comissário José Dantas de Melo, 21, 29102-770 - Vila Velha - ES, Brasil. E-mail: denise.endringer@uvv.br; tadeu.andrade@uvv.br
} 
e flavonóides. ERE exibiu um efeito inibidor da ECA tanto in vitro como in vivo. A seleção das espécies utilizadas na medicina popular como antiofídicos, juntamente com o ensaio in vitro de inibição da ECA, pode ser um método de biomonitoramento para a seleção de novas plantas medicinais com propriedades hipotensores.

Unitermos: Cyperaceae/espécies/farmacognosia. Cyperaceae/espécies/inibição in vitro. Cyperaceae/ espécies/efeito hipotensor. Enzima conversora de angiotensina/inibição in vitro. Flavonoides/ determinação.

\section{INTRODUCTION}

French naturalist August Saint Hillaire, during his stay in ES, noted that locals used some Cyperaceae, Aristilochiaceae and Fabaceae plants to treat wounds caused by snake bites - two of which applied orally and the other one applied locally (Saint-Hillaire, 1820/2002). Regarding the study of antihypertensive plants, the selection can be ethnobotanical, based on species used as diuretics, antidotes and antihypertensives (Ribeiro, et al., 1986). Several species commonly used as antivenins also present anti-inflammatory, antioxidant and hypotensive activity (Balestrin et al., 2008). Species of the Cyperus genus, Cyperaceae family, are reported as anti-inflammatory (Falcão, et al., 2005), antimalarial (Schwikkard, Heerden, 2002) and hepatoprotective extracts (Amani et al., 2012).

Concerning the advanced ecosystem destruction together with the potentialities of the Cyperaceae family, the aim of this study were to identify whether any of the the ethanolic extracts of Cyperaceae species presents an inhibitory effect on in vitro ACE, and whether the most active species in vitro shows an acute hypotensive effect in vivo and ACE inhibitory effect in vivo.

\section{MATERIAL AND METHODS}

\section{Plant materials and extraction}

Ten specimens from Cyperaceae family were harvested (July, 2010) from Paulo César Vinha State Park (PEPCV), with the previous approval of local environmental authorities (IEMA, protocol 629/09). The samples gathered were identified by the botanists Oberdan José Pereira and Márcio Lacerda Lopes Martins, and a voucher specimens were deposited at the herbarium of the Espírito Santo Federal University (UFES, VIES): Bulbostylis capillaris (L.) C.B.Clarke (20³6'22.5"S; $40^{\circ} 25^{\prime} 02.0^{\prime \prime} \mathrm{W}$, VIES 26082 and VIES 26085) Cyperus tenuis Sw. (20³6'12,8"S; 40²5'27.7"W. VIES 26083), Eleocharis intersticta $\operatorname{Vahl}\left(20^{\circ} 36^{\prime} 17.6^{\prime \prime S}\right.$; 40²5'16.1"W, VIES 26380), Remirea maritima Aubl (20³6'33.2"S; $40^{\circ} 24^{\prime} 43.7 " \mathrm{~W}$, VIES 26379), Rhynchospora exaltata Kunth (20³6'22.8"S; 40²5'07.8"W, VIES 26079), Rhynchospora holoschoenoides Rich. (20³6'23.1"S; $40^{\circ} 25^{\prime} 01.09 " \mathrm{~W}$, VIES 26086), Rhynchospora tenuis Link (20³6'17.1"S; 40²5'2.66"W, VIES 26081 and VIES 26087), Scleria secans L. (20 $36^{\prime} 21.5^{\prime \prime S}$; $40^{\circ} 25^{\prime} 10.5^{\prime \prime} \mathrm{W}$, VIES 26080). Two of the ten collected specimens were identified as the same (B. capillaris and R. tenuis).

The collected plants were dryed at $40{ }^{\circ} \mathrm{C}(48 \mathrm{~h})$ and grounded. The ethanolic extract was prepared by successive ultrasound-assisted (15 min, $40 \mathrm{~Hz}$ ) extraction. The extract was then concentrated using a rotatoryevaporator at $40{ }^{\circ} \mathrm{C}$, under low pressure conditions, obtaining the crude ethanolic extract of the species: $B$. capillaris (0.16 g), C. tenuis (0.06 g), E. interstinata $(0.71$ $\mathrm{g})$, R. exaltata $(1.4 \mathrm{~g}), R$. haloschoenoides $(0.8 \mathrm{~g}), R$. tenuis $(0.91 \mathrm{~g})$, R. maì̀tima $(0.3 \mathrm{~g})$ and $S$. secans $(2.1 \mathrm{~g})$.

\section{Determination of total phenolic}

The total phenolic content was determined using Folin-Ciocalteu method, along with some modifications (Singleton, Rossi, 1965). Solutions at a concentration of $1.5 \mathrm{mg} / \mathrm{mL}$ of the ethanolic extracts were prepared. The calibration curve was plotted with a pyrogallol solution (from 10 to $350 \mu \mathrm{g} / \mathrm{mL}$ ), and the equation was $\mathrm{y}=0.001244 \mathrm{x}+0.002889, \mathrm{r}^{2}=0.9977$. The results were expressed as micrograms of pyrogallol equivalents (PE) per milligram of dry sample. The analyses were performed in triplicates. The limit of quantification was $13.7 \mu \mathrm{g} / \mathrm{mL}$ and the limit of detection was $4.1 \mu \mathrm{g} / \mathrm{mL}$.

\section{Dtermination of total flavonoids}

The total flavonoids content was determined by colorimetric aluminum chloride method (Marinova et al., 2005). The calibration curve was prepared with rutin solutions, at the $31.25-1000 \mu \mathrm{g} / \mathrm{mL}$ range. The calibration regression equation was $y=0.0033 x+0.0121, r^{2}=0.9991$. The results were expressed as micrograms of rutin equivalents (RE) per milligram of sample. The analyses 
were done in triplicates. The limit of quantification was $5.3 \mu \mathrm{g} / \mathrm{mL}$ and the limit of detection was $1.6 \mu \mathrm{g} / \mathrm{mL}$.

\section{High performance liquid chromatography (HPLC) analysis}

The analysis of the eight Cyperaceae extracts, especially of ERE by HPLC was performed in a Waters 1515 separation device, along with a binary pump, and an UV/VIS detector (model 2489). The data were processed using the Breeze software. A C18 XBridge reverse-phase column was used ( $150 \times 4.6 \mathrm{~mm}$ i.d., $3.5 \mu \mathrm{m}$, Waters $)$, along with an also C-18 XBridge precolumn $(20 \times 4.6 \mathrm{~mm}$ i.d., $3.5 \mu \mathrm{m}$, Waters), at room temperature. Two isocratic elution systems were used. The first one was composed by a $\mathrm{MeOH}: \mathrm{H}_{2} \mathrm{O}(9: 1)$ solution, wavelength detection at 254 and $365 \mathrm{~nm}$, and isocratic flow at $0.8 \mathrm{~mL} / \mathrm{min}$; the second was employed a $\mathrm{MeOH}: \mathrm{H}_{2} \mathrm{O}: \mathrm{ACN}: \mathrm{AcOOH}: \mathrm{CHOOH}$ (20:10:20:1:1) eluent, same wavelengths, and $1.2 \mathrm{~mL} / \mathrm{min}$ flow. The solvents were HPLC quality (Merck, Darmstadt, Germany), the water was ultrapure (ELGA, 18.2 $\Omega$ ) and was degassed by sonication and vacuum pump prior to use. Both the reference rutin and apigenin solutions (Sigma, St. Louis, USA) and the ERE sample were dissolved in MeOH, HPLC degree (Merck, Darmstadt, Germany). The sample concentration was $1.0 \mathrm{mg} / \mathrm{mL}$. The final concentration of the reference solutions used on the plotting of the standard curve ranged from 0.03 to $0.6 \mu \mathrm{g} / \mathrm{mL}$. Samples, as well as reference solutions, were centrifuged at $8400 \mathrm{~g}$ for $5 \mathrm{~min}$. Each sample and standard solution $(20 \mu \mathrm{L})$ was done manually. All analyses were done in triplicates.

\section{ACE in vitro inhibition assay}

Effects of the Cyperaceae crude ethanolic extracts on $\mathrm{ACE}$ were determined by measuring the accumulation of Gly-Gly (glycine-glycine), the ACE cleavage product of Hip-Gly-Gly. This assay was performed as previously described (Endringer et al., 2014). In brief, the assays were initiated by an addition of $10 \mu \mathrm{L}$ of the sample (final concentration of $100 \mu \mathrm{g} / \mathrm{mL}), 10 \mu \mathrm{L}$ of $\mathrm{MeOH} / \mathrm{HEPES}$ (1: 4), $\mathrm{pH} 8.0$ (negative control), or $10 \mu \mathrm{L}$ of a captopril solution (final concentration of $64 \mathrm{nM}$; positive control) into a 96 -well plate. A rabbit lung solution $(10 \mu \mathrm{L}$ for the final concentration of $9.1 \mathrm{mg} / \mathrm{mL}$ ) was used as the ACE source. The plate was then homogenized and preincubated at $37^{\circ} \mathrm{C}$ for $10 \mathrm{~min}$. The enzymatic reaction was initiated by an addition of $60 \mu \mathrm{L}$ of the HEPES buffer (final concentration of $27.3 \mathrm{mM}$ ), $\mathrm{pH} 8.15$ and $30 \mu \mathrm{L}$ of a Hip-Gly-Gly solution (final concentration of $27.3 \mathrm{mM}$ ).
After the homogenization, the mixture was incubated for $40 \mathrm{~min}$ at $37^{\circ} \mathrm{C}$. The reaction was stopped by an addition of $100 \mu \mathrm{L}$ of $0.3 \mathrm{M}$ sodium tungstate and $100 \mu \mathrm{L}$ of $0.3 \mathrm{M}$ sulfuric acid. In the sequence, an aliquot $(64 \mu \mathrm{L})$ was diluted with $100 \mu \mathrm{L}$ of water and kept in rest for $5 \mathrm{~min}$. Subsequently, the system was mixed with the color reagent 2,4,6trinitrobenzenesulfonic acid solution, TNBS (6.92 mM) (Sigma, USA). The plate was kept in the dark at room temperature for $20 \mathrm{~min}$ and its absorbance was measured using a microplate reader (BioRad, Model 550) at $415 \mathrm{~nm}$. The readings were compared against a blank solution, which was prepared in a similar manner with the exception of sodium tungstate and sulfuric acid solutions being added before the rabbit lung solution. Based on the measured ACE inhibitory activity, the compounds were classified as inactive $(<30 \%)$, weak $(>30 \%$ to $50 \%)$, moderate $(>50 \%$ to $80 \%)$, and strong $(>80 \%)$ inhibitors.

\section{Acute hypotensive assay}

The in vivo experiments were performed according to the ethical principles determined by Brazilian School of Animal Experimentation (COBEA, 1991), and were approved by the Ethical, Bioethical and Animal Welfare Committee (CEUA - UVV, 120/2010). Male Wistar Kyoto (WKY; $n=6)$ and Spontaneously Hypertensive Rats (SHR; $\mathrm{n}=6$ ) were used. The animals were about three months old, with a body weight from 200 to $250 \mathrm{~g}$. The rats were kept at temperatures of $22 \pm 3{ }^{\circ} \mathrm{C}$, in a $12 \mathrm{~h} \mathrm{light} / 12 \mathrm{~h}$ dark cycle, and had free access to standard pellet diet (Probiotério stockfeed, Moinho Primor SA) and water.

Under sodium pentobarbital anesthetic $(50 \mathrm{mg} / \mathrm{kg}$, intraperitonial Hypnol, Crystal, Brasil) (Andrade et al., 2008), both femoral arteries and veins were catheterized (polyethylene catheter, PE 50, Clay Adans, USA). The venous catheter was used for the injection of the raw ethanolic extract from $R$. exaltata (ERE - $267 \mathrm{mg} / \mathrm{mL}$ in saline solution) and/or saline, the arterial catheter was connected to pressure pipes (Spectramed, Statham, P23XL, USA) by a flexible catheter, and the register values of the mean arterial pressure (MAP) were collected by a computer (Pentium MMX $233 \mathrm{MHz}$ ) and by a biological data acquisition software (Biopac, Biopac Systems, USA, mod. 100A/94111065 MP series).

The acute hypotensive effect was evaluated by the plotting of a dose-effect curve of the ERE solution. The WKY and SHR animals received saline $1 \mathrm{~mL} / \mathrm{kg}$ (Soncini et al., 2011) and, afterwards, increasing doses, in bolus, of ERE $(0.01-100 \mathrm{mg} / \mathrm{kg})$. The subsequent dose was administrated only after MAP returned to the levels observed prior to the first application. ACh was utilized as 
positive control ( $5 \mu \mathrm{g} / \mathrm{kg}$, i.v.;) both before and after the ERE curve (Lahlou et al., 2003).

\section{ACE in vivo inhibition assay}

ACE in vivo inhibitory evaluation was performed according to Mangiapane et al. (1994), with slight modifications. Briefly, the effect of angiotensin I (ANGI; $0.03,03$ and $300 \mu \mathrm{g} / \mathrm{kg}$ i.v.) was analyzed before and after the injection of a single dose of ERE ethanolic extract (10 mg/kg, i.v.). As positive control, ANG I was administered before and after captopril (30 mg/kg).

\section{Statistical analysis}

The values of the biological evaluation were expressed as the mean \pm standard error of the mean (S.E.M.). Basic values of MAP and FC, and MAP after ERE's injection were submitted to analysis of variance (ANOVA), followed by a post-hoc Fisher test, $p<0.05$. Correlation coefficient of the standard curves was obtained by linear regression by the least squares method and the data were then analyzed by ANOVA, on a $95 \%$ LC and degree of freedom of $n-1$. The limits of detection (LOD) and quantification (LOQ) were computed by the division of the standard deviation of the slope of the curves on the calibration assay.

\section{RESULTS AND DISCUSSION}

There are just a few taxonomical studies about the Cyperaceae family, which makes it hard to identify and/ or differentiate the species (Martins et al., 1999). From the gathered Cyperaceae specimens, two of them were of the same species (B. capillaris and R. tenuis), and one of them (B. capillaris) is on August de Saint-Hillaire Virtual Herbarium species list (Virtual Herbarium, 2012). $B$. capillaris as well as $R$. exaltata were considered active on the ACE inhibition assay (Table I).

The $50 \%$ inhibitory in vitro ACE concentration $\left(\mathrm{CI}_{50}\right)$ of the active species could not be calculated, as the observed inhibitory effect was dose-independent. The presence of total polyphenols, including tannins, on the extracts might be related to this not specific in vitro inhibition. Nyman et al. (1998), observed that only four species, from the thirteen considered active in the ACE assay, remained presenting dose-dependent inhibitory ACE activity after tannins were removed. Polyphenols, distinctly from flavonoids, might be related to the inhibitory ACE activity of $B$. capillaris species.

However, it is not possible to establish a correlation between the in vitro ACE inhibition percentage and the content of total phenolics, as they might be the constituents related to the ACE inhibitory effect noted for $R$. exaltata (table I). Barbosa-Filho et al. (2006), summarized several studies of the natural products with inhibitory ACE activity and observed that flavonoids and tannins were related to the activity of several species among them: Erythroxylum laurifolium, "Korean" green tea, Allophylus edulis. In the present study, $C$. rotundus, Cyperaceae, was cited, but it did not show ACE inhibition (Barbosa-Filho et al., 2006).

The two species showing the most effective ACE inhibition were $B$. cappilaris and $R$. exaltata. Due to the available amount of active samples, $R$. exaltata was chosen for the in vivo hypotensive study. The chromatographic profile obtained for ERE was simple, on the analyzed wavelengths, with a dominance of polar substances,

TABLE I - ACE inhibition percentages, total polyphenols and flavonoids amounts for the analyzed Cyperaceae species

\begin{tabular}{lccc}
\hline & $\%$ ACEI $^{\mathbf{a}}$ & Total polyphenols $^{\mathbf{b}}$ & Total flavonoids $^{\mathbf{c}}$ \\
\hline Captopril $^{\mathbf{c}}$ & $73.2 \pm 20.0$ & & \\
Bulbostylis capillaries $_{\text {Cyperus tenuis }}{ }^{\mathbf{d}}$ & $86.9 \pm 15.2$ & $141.0 \pm 16.1$ & $11.0 \pm 3.6$ \\
Eleocharis interstincta $^{\text {Remiria maritime }}$ & $\mathrm{NA}$ & $\mathrm{NA}$ & $\mathrm{NA}$ \\
Rhynchospora exaltata & $30.7 \pm 7,8$ & $30.1 \pm 1.9$ & $31.2 \pm 5.0$ \\
Rhynchospora tenuis & $\mathrm{NA}$ & $92.4 \pm 3.4$ & $34.3 \pm 2.1$ \\
Rhynchospora haloschoenoides & $74.9 \pm 12.0$ & $36.7 \pm 4.9$ & $125.8 \pm 2.9$ \\
Scleria secans & $50.4 \pm 23.2$ & $163.5 \pm 18.3$ & $149.2 \pm 9.0$ \\
\hline
\end{tabular}

anhibition percentage of ACE. ${ }^{b}$ Results presented as micrograms of pyrogallol equivalents per milligram of sample. ${ }^{c}$ Results presented as micrograms of rutin equivalents per milligram of sample. ${ }^{\mathrm{N}} \mathrm{NA}$ : not evaluated due to the available mass. 
suggesting the presence flavonoid-like compounds. Using particular flavonoid eluents, in comparison with rutin and apigenin, peaks related to aglycones, but an overlap of peaks related to glycolized flavonoids (rutin and others).

As expected MAP of SHR $(182 \pm 8 \mathrm{mmHg} ; \mathrm{p}<0.01)$ animals was higher compared with WKY $(99 \pm 5 \mathrm{mmHg})$. During the acute hypotensive assay, the ethanolic crude extract of $R$. exaltata determined a reduction of the pressure levels in a dose-dependent way in both normotensive and hypertensive animals (Figure 1), which were statistically different from the reduction caused by the saline injection (WKY: $-7.6 \pm 3 \mathrm{mmHg}$; SHR: $-8 \pm 4 \mathrm{mmHg}$ ). Reductions elicited in SHR animals were greater compared with WKY (Figure 1). ACh induced a hypotensive effect before and after ERE's curve (WKY: $-43.2 \pm 4 \mathrm{mmHg}$ and $-44.3 \pm 3 \mathrm{mmHg}$; SHR: $-74 \pm 5 \mathrm{mmHg}$ and $-78 \mathrm{mmHg} ; \mathrm{p}<0.01$ compared with WKY), suggesting vascular integrity, as the vascular relaxation induced by $\mathrm{ACh}$ is dependent on the integrity of endothelial cells (Batlouni, 2001). The in vivo ACE inhibition of ERE is reported in Table II. ANGI at all tested doses $(0.03,3.0$, $300.00 \mu \mathrm{g} / \mathrm{kg}$ ) increased the MAP (Table II, before CAP and before ERE). ERE decreased around $50 \%$ of the ANGI effect (Table II), indicating that ERE inhibits ACE in vivo. However, the design of the in vivo inhibition assay applied in the present study does not differ between the two ACE isoforms and also not between AngII and its metabolite, Ang 1-7. ACE and ACE2 isoforms are 40\% similar (Watermeyer et al., 2006; Sturrock et al., 2004). ACE2 acts as a carboxylpeptidase, whereas ACE acts as a peptidylpeptidase (Brown, Hall, 2005). Several studies indicate that both enzymes, ACE and ACE2, have similar catalytic mechanisms. However, the ACE inhibitory agents, such as captopril, lisinopril, are inactive against ACE2. These data suggest that the proteolytic activity of ACE2 is different from the isoform ACE. Unlike ACE,

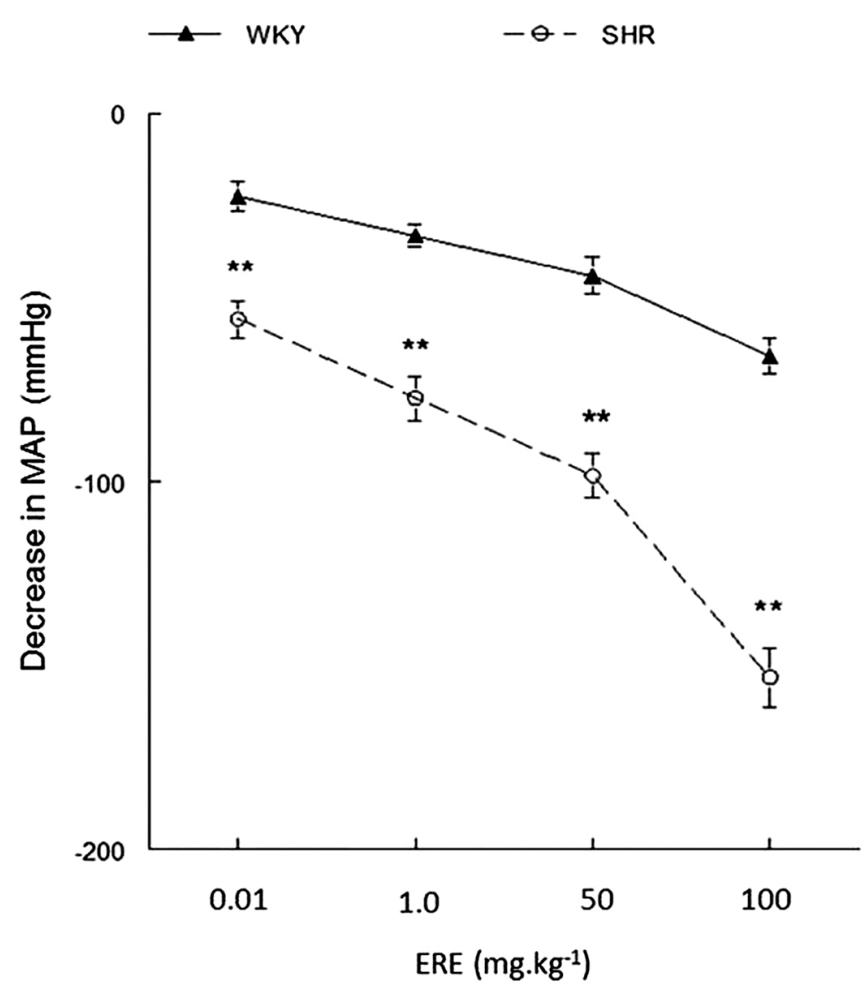

FIGURE 1 - ERE-induced dose-dependent reduction in Mean Arterial Pressure (MAP) in normotensive (WKY) and hypertensive (SHR) animals. ERE: ethanolic extract of Rhynchospora exaltata. The values are presented as the mean \pm S.E.M. ${ }^{* *} \mathrm{p}<0.01$ compared WKY.

ACE2 is the monopeptidilcarboxipeptidase (Guy et al., 2003; Warner et al., 2004; Guy et al., 2005).

Some species analyzed applying a similar assay used in the present study also showed hypotensive activity (Singi et al., 2005; Soncini et al., 2011). Soncini et al. (2011) reported that aqueous extract of Averrhoa carambola L. (Oxalidaceae) showed a dosedependent pressure reduction. The hypotensive activity

TABLE II - Mean arterial pressure (MAP) increase induced by the injection of ANG I (0.03, 3 and $300 \mu \mathrm{g} / \mathrm{kg}$, i.v. $)$ before and after injection of the ethanolic extract of Rhynchospora exaltata (ERE; $10 \mathrm{mg} / \mathrm{kg}$ ) and captopril (CAP; $30 \mathrm{mg} / \mathrm{kg}$, triangles)

\begin{tabular}{lccccccccc}
\hline \multirow{2}{*}{ Groups } & \multicolumn{7}{c}{ ANG I $(\mu \mathrm{g} / \mathrm{kg})$} \\
\cline { 2 - 10 } & $\mathrm{MAP}_{\mathrm{B}}$ & $\mathrm{MAP}_{\mathrm{A}}$ & $\Delta \mathrm{MAP}$ & $\mathrm{MAP}_{\mathrm{B}}$ & $\mathrm{MAP}_{\mathrm{A}}$ & $\Delta \mathrm{MAP}$ & $\mathrm{MAP}_{\mathrm{B}}$ & $\mathrm{MAP}_{\mathrm{A}}$ & $\Delta \mathrm{MAP}$ \\
\hline Before CAP & $96 \pm 4$ & $126 \pm 5$ & $32 \pm 4$ & $98 \pm 3$ & $153 \pm 6$ & $56 \pm 4$ & $92 \pm 5$ & $190 \pm 8$ & $104 \pm 6$ \\
After CAP & $94 \pm 3$ & $99 \pm 4^{* *}$ & $4 \pm 2^{* *}$ & $93 \pm 4$ & $101 \pm 3^{* *}$ & $8 \pm 3^{* *}$ & $91 \pm 6$ & $105 \pm 5^{* *}$ & $12 \pm 4^{* *}$ \\
Before ERE & $92 \pm 4$ & $124 \pm 6$ & $34 \pm 5$ & $95 \pm 3$ & $146 \pm 5$ & $49 \pm 6$ & $93 \pm 4$ & $192 \pm 7$ & $100 \pm 8$ \\
After ERE & $95 \pm 2$ & $108 \pm 3^{* *}$ & $14 \pm 4^{* *++}$ & $96 \pm 5$ & $124 \pm 4^{* *+}$ & $31 \pm 5^{* *++}$ & $92 \pm 4$ & $143 \pm 6^{* *+}$ & $53 \pm 5^{* *++}$ \\
\hline
\end{tabular}

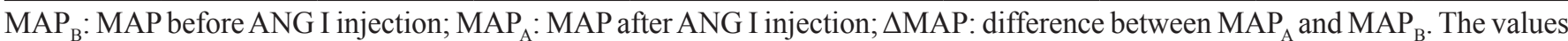
are presented as the mean \pm S.E.M. ${ }^{* *} \mathrm{p}<0.01$ compared with MAP values before CAP or ERE administration. ${ }^{++} \mathrm{p}<0.01$ compared with MAP after CAP administration. 
of hydroalcoholic extracts of garlic (Allium sativum L.) and lemon-grass (Cymbopogon citratus (DC) Stapf) were reported by Singi et al. (2005).

The data reported in the present study indicate that some Cyparaceae species have ACE in vitro inhibitory activity, being related with the high content of total flavonoids and phenolics. ERE exhibited an inhibitory effect on both in vitro and in vivo ACE. The selection of species used in popular medicine as antidotes, along with the in vitro assay of ACE inhibition, might be a biomonitoring method for the screening of new medicinal plants with hypotensive properties.

\section{ACKNOWLEDGEMENTS}

UVV and FAPES are thanked for the financial support. FUNADESP and FAPES are acknowledged for the fellowships provided for the authors.

\section{REFERENCES}

AMANI, S.A.; GAMAL, A.S.; DALIA, F.E.; OMIMAH, D.E.; SALEH, I.A. Hepatoprotective activity of Cyperus alternifolius on carbon tetrachloride-induced hepatotoxicity in rats. Pharm. Biol., v.50, n.2, p.155-161, 2012.

ANDRADE, T.U.; ABREU, G.R.; MOYSÉS, M.R.; CABRAL, A.M.; BISSOLI, N.S. Role of cardiac hypertrophy in reducing the sensitivity of cardiopulmonary reflex control of renal sympathetic nerve activity in spontaneously hypertensive rats. Clin. Exp. Pharmacol. Physiol., v.35, n.9, p.1104-1108, 2008.

BALESTRIN, L.; DIAS, J.F.G.; MIGUEL, O.G.; DALL'STELLA, D.S.G.; MIGUEL, M.D. Contribuição ao estudo fitoquímico de Dorstenia multiformis Miquel (Moraceae) com abordagem em atividade antioxidante. Rev. Bras. Farmacogn., v.18, n.2, p.230-235, 2008.

BARBOSA-FILHO, J.M.; MARTINS, V.K.M.; RABELO, L.A.; MOURA, M.D.; SILVA, S.; CUNHA, E.V.L.; SOUZA, M.F.V.; ALMEIDA, N.A.; MEDEIROS, I.A. Natural products inhibitors of the angiotensin converting enzyme (ACE). A review between 1980 - 2000. Rev. Bras. Farmacogn., v.16, n.3, p.421-446, 2006.

BATLOUNI, M. Endotélio e hipertensão arterial. Rev. Bras. Hipertens., v.8, n.3, p.328-338, 2001.
EL-BERTAGI, H.S.; SALAMA, Z.A.; EL-HARIRI, D.M. Evaluation of fatty acids profile and the content of some secondary metabolites in seeds of different flax cultivars (Linum usitatissimum L.). Ge. Appl. Plant Physiol., v.33, n.3-4, p.187-202, 2007.

ENDRINGER, D.C.; OLIVEIRA, O.V.; BRAGA, F.C. In vitro and in silico inhibition of angiotensin-converting enzyme by carbohydrates and cyclitols. Chem. Papers, v.68, n.1, p.37-45, 2014.

FALCÃO, H.S.; LIMA, I.O.; SANTOS, V.L.; DANTAS, H.F.; DINIZ, M.F.F.M.; BARBOSA-FILHO, J.M.; BATISTA, L.M. Review of the plants with anti-inflammatory activity studied in Brazil. Rev. Bras. Farmacogn., v.15, n.4, p.381391, 2005.

GUY, J.L.; JACKSON, R.M.; ACHARYA, K.R.; STURROCK, E.D.; HOOPER, N.M.; TURNER, A.J. Angiotensinconverting enzyme-2 (ACE2): comparative modelling of the active site, substrate specificity and chloride dependence. Biochemistry, v.42, n.45, p.13185-13192, 2003.

GUY, J.L.; LAMBERT, D.W.; WARNER, F.J.; HOOPER, A.J.; TURNER, A.J. Membrane-associated zinc peptidases families: comparing ACE and ACE2. Biochim. Biophys. Acta, v.1751, n.1, p.2-8, 2005.

HERBÁRIO Virtual A. De Saint-Hilaire, 2012. Available at: $<$ http://hvsh.cria.org.br>, Accessed on: Feb. 2012.

LAHLOU, S.; INTERAMINENSE, L.F.L.; LEA-CARDOSO, J.H.; DUARTE, G.P. Antihypertensive effects of the essential oil of Alpinia zerumbet and its main constituent, terpinen-4-ol, in DOCA-salt hypertensive conscious rats. Fundam. Clin. Pharmacol., v.17, n.3, p.323-330, 2003.

MANGIAPANE, M.L.; RAUCH, A.L.; MACANDREW, J.T.; ELLERY, S.S.; HOOVER, K.W.; KNIGHT, D.R.; JOHNSON, H.A.; MAGEE, W.P.; CUSHING, D.J.; BUCHHOLZ, R.A. Vasoconstrictor action of angiotensin I-convertase and the synthetic substrate (Pro11,D-Ala12)angiotensin I. Hypertension, v.23, n.2, p.857-860, 1994.

MARINOVA, D.; RIBAROVA, F.; ATANASSOVA, M. Total phenolics and total flavonoids in bulgarian fruits and vegetables. J. Univ. Chem. Technol. Metallurgy, v.40, n.3, p.255-260, 2005. 
MARTINS, L.L.M.; CARVALHO-OKANO, R.C.; LUCEÑO, M. Cyperaceae do Parque Estadual Paulo César Vinha, Guarapari, Espírito Santo, Brasil. Acta Bot. Bras., v.13, n.2, p.187-222, 1999.

NYMAN, U.; JOSHI, P.; MADSEN, L.B.; PEDERSEN, T.B.; PINSTRUP, M.; RAJASEKHARAN, S.; GEORGE, V.; PUSHPANGADAN, P. Ethnomedical information and in vitro screening for angiotensin-converting enzyme inhibition of plants utilized as traditional medicines in Gujarat, Rajasthan and Kerala (India). J. Ethnopharmacol., v.60, n.3, p.247-263, 1998.

RIBEIRO, R.A.; MELO, M.M.R.F.; BARROS, F.; GOMES, C.; TROLIN, G. Acute antihypertensive effects in conscious rats produce by some medicinal plants used in the state of São Paulo. J. Ethnopharmacol., v.15, n.3, p.261-269, 1986.

SAINT-HILAIRE, A. Viagem ao Espírito Santo e Rio Doce. Vitória: Secretaria Municipal de Cultura, 2002. 128 p.

SCWHIKKARD, S.; HEERDEN, F.R.V. Antimalarial activity of plant metabolites. Nat. Prod. Rep., v.19, p.675-692. 2002.
SINGI, G.; DAMASCENO, D.D.; D’ANDREA, E.D.; SILVA, G.A. Efeitos agudos dos extratos hidroalcoólicos do alho (Allium sativum L.) e do capim-limão (Cymbopogon citratus (DC) Stapf) sobre a pressão arterial média de ratos anestesiados. Rev. Bras. Farmacogn., v.15, n.2, p.94-97, 2005.

SINGLETON, V.L.; ROSSI, J.A.J.R. Colorimetry of total phenolics with phosphomolybdic-phosphotungstic acid reagents. Am. J. Enol. Vitic., v.16, n.3, p.144-158, 1965.

SONCINI, R.; SANTIAGO, M.B.; ORLANDI, L.; MORAES, G.O.; PELOSO, A.L.; SANTOS, M.H.; ALVES-DASILVA, G.; PAFFARO, V.A.; BENTO, A.C.; GIUSTIPAIVA, A. Hypotensive effect of aqueous extract of Averrhoa carambola L. (Oxalidaceae) in rats: an in vivo and in vitro approach. J. Ethnopharmacol., v.133, n.2, p.353-357, 2011.

WARNER, F.J; SMITH, A.I.; HOOPER, N.M.; TURNER, A.J. Angiotensin-converting enzyme-2: a molecular and cellular perspective. Cell Mol. Life Sci., v.61, n.21, p.2704-2713, 2004. 